\title{
Emotional Intelligence, Work Family Conflict, and Job Satisfaction on Junior High School Teacher's Performance
}

\author{
Dewie Tri Wijayati ${ }^{1}$, Achmad Kautsar ${ }^{2}$ \& Karwanto Karwanto ${ }^{3}$ \\ 1,2 Departement of Management, Universitas Negeri Surabaya, Surabaya, Indonesia \\ ${ }^{3}$ Departement of Education Management, Universitas Negeri Surabaya, Surabaya, Indonesia \\ Correspondence: Achmad Kautsar, Departement of Management, Universitas Negeri Surabaya, Surabaya, East Java, \\ Indonesia.
}

Received: November 17, 2019

Accepted: December 10, $2019 \quad$ Online Published: December 11, 2019

doi:10.5430/ijhe.v9n1p179

URL: https://doi.org/10.5430/ijhe.v9n1p179

\begin{abstract}
Female workers do not always get the same rights as their male colleagues. Many women are forced to dispel their desires to become structural career women because they are unable to compete with men. Therefore, it is necessary to have clear performance measurements to prove that female teachers also have good performance. The research was conducted using explanatory research with a quantitative approach. The test was conducted by SEM analysis techniques using AMOS. The study found a significant influence between Emotional Intelligence on Job Satisfaction as well as Job Satisfaction on Commitment. In the next test it was found that Job Performance was only influenced by family conflict in a negative direction, while Commitment and Job Satisfaction had no effect on Job Performance.
\end{abstract}

Keywords: emotional intelligence, job satisfaction, commitment, work family conflict, job performance

\section{Introduction}

The phenomenon in Indonesia which views women as weak and less capable is gradually eroded by historical facts. The increasing level of education is the turning point of this phenomenon. In the present, many Indonesian women have won the highest position in the business, social, political and educational organizational structures. This cause teacher becomes a profession that is quite attractive to be occupied by women in Indonesia.

Some facts in the work environment, not all women have the same rights as their male colleagues. Many women are forced to dispel their desires to become structural career women because they are unable to compete with men. Therefore, it is necessary to have clear performance measurements to prove that a female teacher also has good performance. The study by Vermeeren et al. (2009) proved that Job Performance measurement can help public organizations to improve the quality of their services. In general, organizational performance is still an interesting topic in a study (Kistyanto et al, 2018; and Wardoyo et al, 2018).

Some studies have found that female teachers have higher skills than male teachers (Raudenbush et al., 1992; and Ross et al., 1996). Both studies were conducted because respondents thought that educating was seen as a woman's expertise. But there is a gap from the results of the research by Lee et al. (1991) which showed no difference in performance between male and female teachers. In fact, Klassen and Chiu (2010) even found that female teachers only had the ability to manage lower classes compared to male teachers.

Several factors can affect a person's performance. The first factor in this study was Emotional Intelligence. Parker et al (2009) argue that high Emotional Intelligence can contribute to more effective teaching and better performance among teachers. According to Penrose et al (2007), teachers with higher Emotional Intelligence have a better understanding of students' emotional needs as well as more effective management of emotional feedback, thereby improving their performance. This study developed a research model from Latif \& Khan (2017), which state that teachers with high Emotional Intelligence tend to have high Job Satisfaction, so that they have a high Commitment to the organization and show good performance to the school for a longer period of time. In addition, schools will get better results by hiring teachers who have high Emotional Intelligence.

Factor other than Emotional Intelligence that can affect Job Satisfaction is work and family conflict. Multiple role conflicts have been studied previously to measure the level of Job Satisfaction and Job Performance. Some studies have found that the results of work-to-family and family-to-work conflict have a negative influence on Job 
Satisfaction (Beutell, 2010; Karatepe and Kilic, 2007; Spector et al., 2007). If a person's role in his job increases and he is increasingly important, often they feel that family is a threat that disrupts their time and energy. Thus, they create a negative attitude to the family and role conflict (Beutell, 2010; Grandey et al., 2005).

Job Satisfaction is basically an individual matter. Each individual will have a level of satisfaction that varies according to the system value that applies to them. The more aspects of work that are in accordance with individual intentions, the higher the level of satisfaction felt (As'ad, 2005). Lok and Crawford (2001) as well as McNeese-Smith (2001) found that there was a positive relationship between Job Satisfaction and organizational commitment. The more satisfied someone is with his/her job, the more committed he/she is.As a result, employees develop commitment to the organization, resulting in improved work performance (Piening et al, 2013). Lok and Crawford (2001) as well as McNeese-Smith (2001) found that there was a positive relationship between Job Satisfaction and organizational commitment.

\section{Literature Review}

\subsection{Job Performance}

Job Performance is one of the important factors in managing human resource activities and building organizations (Segal, 1992). Empirical studies that propose Job Performance as a multidimensional concept that can be task-oriented by embracing contextual actors consist of social skills associated with desired Job Performance (Hochwarter et al, 2004). Job Performance is identified important for gaining competitive advantage and achieving greater productivity in an organization (Shaffril and Uli, 2010). In particular, Job Performance refers to the actions of people on their work that can contribute to the organization's goals and are under the power of individuals (Rotundo and Rotman, 2002). Berghe (2011) defines Job Performance as an effort made by someone to do a task or work. If Job Performance varies from one job to another, then Job Performance can vary according to the number of tasks, the tasks itself, and responsibilities they have to do (Jacobs and Winslow, 2004).

\subsection{Job Satisfaction}

Job Satisfaction is defined as a pleasant or positive emotional state that results from the assessment of one's work or work experience (Locke, 1976). Comfortable in the workplace or satisfaction with work is very important for employees and the organization. A recent analysis found that higher employee's Job Satisfaction is associated with higher customer satisfaction (Mendoza \& Maldonado, 2014). Employees with higher Job Satisfaction also work better in the workplace (Davar\&Bala, 2012) and have more organizational commitment (Magnini et al., 2011). Furthermore, higher Job Satisfaction is less likely to be involved in family conflict (Chen et al., 2015) more subjective well-being such as life satisfaction and happiness (Halkos\&Bousinakis, 2010).

Job Satisfaction is defined as employees' internal evaluations of their work conditions and their level of success along with personal values (Yavas et al, 2013). Various steps can be taken to evaluate the degree of Job Satisfaction such as making direct interviews or voice-to-vote interviews, or even interviewing them to collect data about weak points and / or company strengths that affect their satisfaction (Dumitrescu et al, 2012).

\subsection{Commitment}

Organizational commitment means employees' loyalty to their organization and procedures collaborated by employees in organizational decision making (Awais et al, 2015). Balfour and Wechsler (1996) define organizational commitment as the desire of employees to remain in the organization. According to Chen (2006), organizational commitment is the feeling of employees towards their organization. Organizational commitment is a valuable reaction to the entire organization.

Arriaga and Agne (2001) define Commitment as a psychological state that involves affective, cognitive, and conative components. Affective components involve psychological attachment to a relationship; the cognitive component requires assumptions from long-term orientation; and finally, the conative component is the intention to survive. According to Robbins (2008), Commitment is a condition in which an employee identifies with a particular organization and wishes to maintain membership in the organization. Luthans (1995) explains that organizational commitment is often defined as; (1) strong desire for someone to become a member of the organization, (2) willingness to mobilize effort for the organization, and (3) trust and acceptance of values and goals of the organization. In other words, organizational commitment is an attitude that shows employees' "loyalty" and the ongoing process of how members of an organization express their concern for the success and virtue of the organization. 


\subsection{Emotional Intelligence}

Bandura (1997) research shows that an important component for Emotional Intelligence is self-awareness, self-regulation, and other people's emotional control. Emotional Intelligence refers to the inherent ability of individuals to handle their emotions (Mayer \&Salovey, 1993) using self-control, perseverance, and self-motivation including managing emotions, understanding one's own emotions, identifying other people's emotions, and handling interpersonal relationships (Goleman, 1996).

Among researchers who define Emotional Intelligence, stand out with comprehensive work definitions and strong applications for organizational leadership functions. First, emotion and leadership (George, 2000) are models that divide Emotional Intelligence into four main categories, namely the assessment of expressions and emotions, the use of emotions to improve cognitive processes and decision making, knowledge of emotions, and emotional management. Goleman (2004) suggests five main components of emotional intelligence:

1. Self-awareness: Recognize and understand your own moods and motivations, as well as their influence on others. To achieve this, you must be able to monitor your own emotional state and identify your own emotions.

2. Self-regulation: Control your impulses, instead of hurrying to react rashly, you can control your emotions and think before responding. Express yourself properly.

3. Internal Motivation: Internal motivation is marked by interest in learning. This is also self-improvement vs. chasing status and status (as wealth pursuit and status are external motivators).

4. Empathy: The ability to understand other people's emotional reactions. This is only possible when someone reaches self-awareness, because people cannot understand others until they understand themselves.

5. Social Skills: Identify social cues to build common ground, manage relationships, and build networks.

\subsection{Work Family Conflict}

Role theory proposes that people play many roles, where the role of work and family are the two most important life roles for most people (Grandey et al., 2005). Foley et al. (2005) differentiated family work conflicts into two forms, depending on direction: Work Family Conflict and Family Work Conflict. Work Family Conflict occurs when personnel experience high demand at work, and pressure occurs because of the high workload when carrying out their role in the work domain, so that it will be difficult for them to fulfill their role in the family domain (Netemeyer et al. 1996).

Netemeyer et al. (1996) states that Work Family Conflict (Work Interference with Family/WIF) is a form of conflict between roles where public demands, time devoted to, and tensions created by work interfere with carrying out family responsibilities, while Family Work Conflicts (Family Interference with Work/FIW) is a form of conflict between roles in which general demands, time devoted to, and tensions created by families interfere with the implementation of work-related responsibilities. Therefore, when there are threats to roles, people tend to assess negative antecedents of threats to roles (Shockley \&Singla, 2011).

\section{Research Model}

The type of research used was explanatory with a quantitative approach. The location of the research was the City of Surabaya, East Java Province. The study population was female teachers in junior high schools in Surabaya. Sampling in this study was carried out using certain considerations (Ferdinand, 2000), based on the criteria for the SEM model using AMOS 18, the appropriate sample size for this study were 200 female teachers. Based on the number of samples chosen according to purposive sampling criteria, namely female teachers whose status is permanent employee at the school, because with their fixed status will make certain satisfaction with female teachers. Before conducting SEM analysis, first test the validity, reliability, and outliers. There are seven steps taken in analyzing SEM, namely: (1) Developing a Model Based on Theory, (2) Arranging a Diagram of Pathways, (3) Arranging Structural Equations, (4) Choosing Model Input Matrix and Estimation (5) Assessing Identification of Structural Models, (6) Assessing Goodness-Of-Fit Criteria, (7) Model Interpretation and Modification.

\section{Result and Discussion}

\subsection{Confirmatory Factor Analysis}

This confirmatory factor analysis is the measurement stage of the dimensions that form latent variables in the research model. As with ordinary factor analysis, the purpose of confirmatory factor analysis is to test the 
unidimensionality of the dimensions forming each latent variable. The results of the confirmatory factor analysis of each model will then be discussed.

\subsubsection{Confirmatory Factor Analysis: Exogenous Construct}

The latent Emotional Intelligence variable in the confirmatory model consists of 6 indicators as its forming dimensions. And the variable Work to Family Conflict consists of 6 indicators as dimensions. The results of data processing for the first construct in the confirmatory factor analysis still have not exceeded the minimum threshold of the goodness of fit indices. There is still a GFI test value below 0.600 , therefore it is necessary to eliminate the indicator, so that it extracts a latent variable.

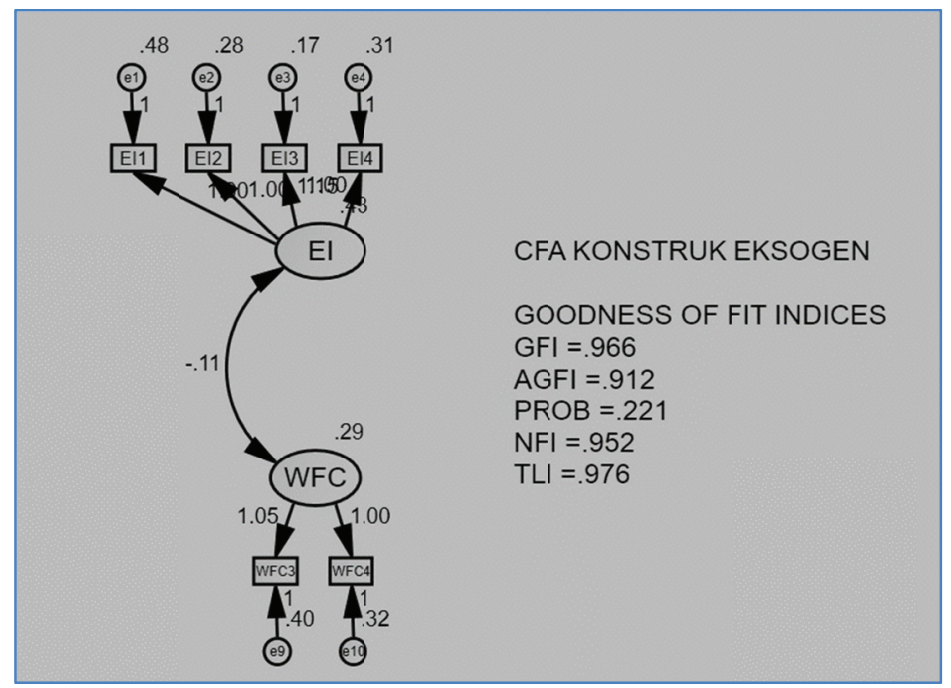

Figure 1. CFA for WFC and EI after modification

Table 1. Result eksogen construct after modification

\begin{tabular}{cccc}
\hline $\begin{array}{c}\text { GOODNESS OF FIT } \\
\text { INDICES }\end{array}$ & CUT OFF & RESULT & CONDITION \\
\hline GFI & $>0.900$ & 0.966 & Good \\
AGFI & $>0.900$ & 0.912 & Good \\
PROB & $>0.050$ & 0.221 & Good \\
NFI & $>0.900$ & 0.952 & Good \\
TLI & $>0.950$ & 0.976 & Good \\
CFI & $>0.900$ & 0.968 & Good \\
\hline
\end{tabular}

The results of exogenous construct testing in figure 1 and table 1, which analyzed the constructs of Work to Family Conflict and Emotional Intelligence, showed that GFI values were above 0.900, and the Standardized Regression Weights values were above 0.500 , so it could be said to be good. This construct is considered valid, reliable, and can be continued to the SEM model.

\subsubsection{Confirmatory Factor Analysis: Endogenous Construct}

Latent variables: Job Satisfaction, Job Performance, and Commitment in the confirmatory model consist of 19 indicators as the forming dimension. The results of data processing analysis show that all constructs used to form a research model in the confirmatory factor analysis process have not met the established criteria for goodness of fit, even though they have experienced improvements from the previous phase. Based on the results of data processing, the results of the goodness of fit have not been good, therefore modifications are needed by removing indicators that 
have values below 0.500 . The next step is to modify the index by removing the Par indicator which has a large value. Based on the results above, the image of the endogenous construct changes again with the following display:

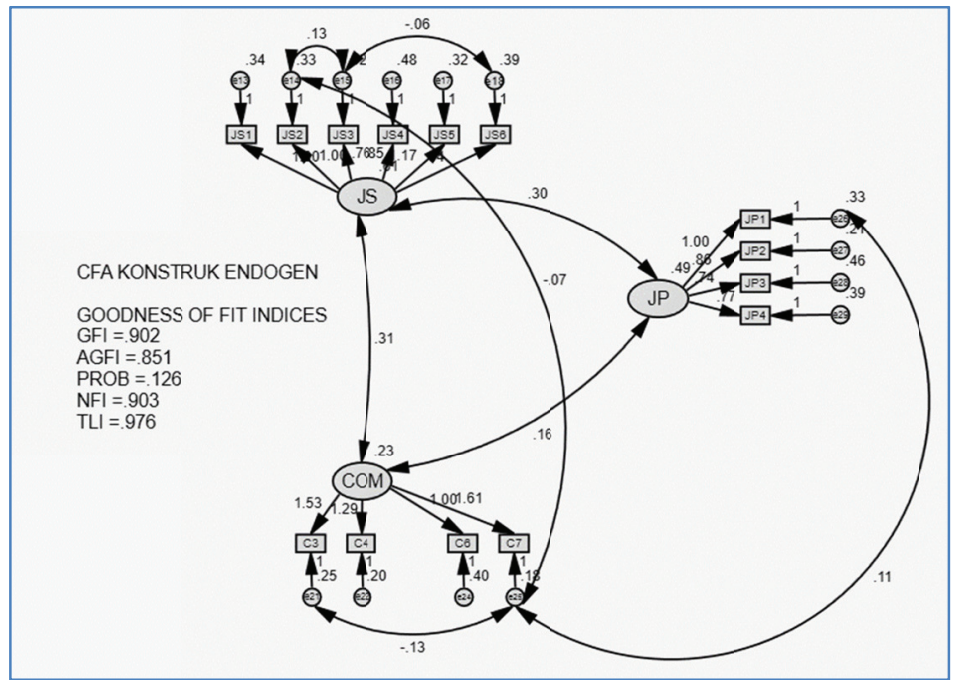

Figure 2. CFA for JS, JP and COM after modification

Table 2. Result endogen construct after modification

\begin{tabular}{cccc}
\hline $\begin{array}{c}\text { GOODNESS OF FIT } \\
\text { INDICES }\end{array}$ & CUT OFF & RESULT & CONDITION \\
\hline GFI & $>0.900$ & 0.902 & Good \\
AGFI & $>0.900$ & 0.851 & Good \\
PROB & $>0.050$ & 0.126 & Good \\
NFI & $>0.900$ & 0.903 & Good \\
TLI & $>0.950$ & 0.976 & Good \\
CFI & $>0.900$ & 0.934 & Good \\
\hline
\end{tabular}

The results of endogenous construct testing in figure 2 and table 2, which analyzed the variable constructs of Job Satisfaction, Commitment, and Job Performance, showed that the GFI value was above 0.900, and the Standardized Regression Weights value was above 0.500 , so it could be said to be good. This construct is considered valid, reliable, and can be continued to the SEM model.

\subsection{Structural Equation Modeling (SEM) Analysis}

The next analysis is the analysis of the Structural Equation Model (SEM) in full model, provided that a unidimensionality level analysis of the indicators forming latent variables has been analyzed by confirmatory factor analysis. Analysis of the data processed at the full stage of the SEM model was carried out by conducting suitability tests and statistical tests. Based on the index modification, the model undergoes image changes where between high Par change is connected through the correlation line. 


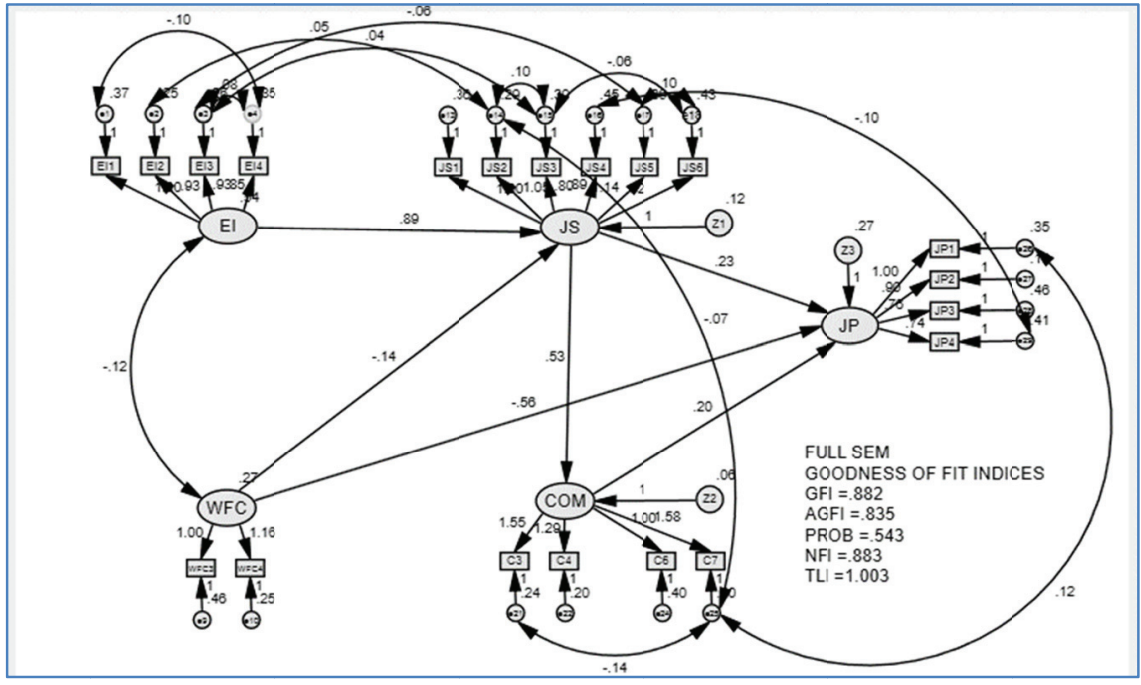

Figure 3. Full Model SEM after modification

Table 3. Result full model after modification

\begin{tabular}{cccc}
\hline $\begin{array}{c}\text { GOODNESS OF FIT } \\
\text { INDICES }\end{array}$ & CUT OFF & RESULT & CONDITION \\
\hline GFI & $>0.900$ & 0.882 & Good \\
AGFI & $>0.900$ & 0.835 & Marginal \\
PROB & $>0.050$ & 0.543 & Good \\
NFI & $>0.900$ & 0.883 & Good \\
TLI & $>0.950$ & 1.003 & Good \\
CFI & $>0.900$ & 0.915 & Good \\
\hline
\end{tabular}

These results indicate that the model used is acceptable. The significance level of 0.882 indicates a good structural equation model. The GFI, AGFI, TLI, NFI, CFI, and PROB measurement indices are within the range of expected values, even though AGFI is marginally accepted.

\subsection{SEM Assumption Test}

\subsubsection{Multivariate Outliers}

Factor analysis also shows the testing value of each constructor. The results show that each indicator or forming dimension of each latent variable shows good results, indicated by values with CR above 1.96 or with probabilities smaller than 0.05 . With these results, it can be said that indicators forming latent variables have shown unidimensionality. Furthermore, based on confirmatory factor analysis of this construct, the research model can be used for further analysis.

\subsubsection{Data Normality}

The next test is to look at the level of data normality used in this study. Testing is done by observing the skewness value in the data used with the provision of CR value of data skewness is in the range between +2.58 or at the significance level of 0.01 . Normality evaluation is carried out using the critical ratio skewness value and kurtosis value criteria, when the second value of the ratio has a value greater than the absolute value of 2.58 , meaning that the data is abnormally distributed. From the results of data processing shown in Table 5.3, it appears that there is no CR value for skewness that is outside the range of +2.58 . Thus the research data used has met the requirements for normality of data, or it can be said that the research data has been normally distributed. 


\section{Discussion}

Table 4. Hypothetical Test

\begin{tabular}{cccccccc}
\hline & & & Estimate & S.E. & C.R. & P & Label \\
\hline JS & $<---$ & WFC & -.139 & .127 & -1.091 & .275 & par_15 \\
JS & $<---$ & EI & .893 & .129 & 6.939 & $* * *$ & par_19 \\
COM & $<---$ & JS & .532 & .093 & 5.705 & $* * *$ & par_17 \\
JP & $<---$ & JS & .229 & .204 & 1.118 & .264 & par_16 \\
JP & $<---$ & COM & .201 & .312 & .646 & .518 & par_20 \\
JP & $<---$ & WFC & -.564 & .198 & -2.845 & .004 & par_21 \\
\hline
\end{tabular}

\subsection{Effect of Emotional Intelligence on Job Satisfaction}

The estimation parameter for testing the Emotional Intelligence influence on Job Satisfaction shows a CR value of 6.939 and a probability of 0,000 . Based on these values it can be concluded that Emotional Intelligence has a significant positive effect on Job Satisfaction. In other words, the higher the Emotional Intelligence of a female junior high school teacher in Surabaya, the higher Job Satisfaction of the teacher will increase.

This result is in line with previous research conducted by Gardner (2006); Latif et al (2017) where Emotional Intelligence is effective in increasing Job Satisfaction. These results can occur because teachers with high Emotional Intelligence are able to show a more effective response to unwanted situations (Perry \& Ball, 2007). These results support the statement of Fernández, et al (2008) that teachers with high Emotional Intelligence tend to create a more effective learning environment and more effectively overcome the behavioral challenges that will later produce satisfaction in work.

\subsection{Effect of Work Family Conflict on Job Satisfaction}

The estimation parameter for testing the effect of Work Family Conflict on Job Satisfaction shows a CR value of $-1,091$ and a probability of 0,275 . Based on these values it can be concluded that Work Family Conflict has no effect on Job Satisfaction. In other words, the high or low level of work family conflict in a female junior high school teacher in Surabaya has no effect on the level of her Job Satisfaction.

The results of this study can occur when the female teachers are able to control family conflict in work with Job Satisfaction based on adequate compensation and pride in being a teacher. Linh et al (2016) research also shows that Work Family Conflict does not have a significant effect on Job Satisfaction of employees in state-owned companies and foreign investment companies. These results are also consistent with $\mathrm{Lu}$ et al. (2010) who found that Work Family Conflict may have less adverse effects on workers because of tolerance between the two domains of life, because work is considered a way to carry out family duties and is reasonable when work assignments are brought home provided they can contribute to family welfare (Aryee et al., 1999).

\subsection{The Effect of Job Satisfaction on Commitment}

The estimation parameter to test the effect of Job Satisfaction on Commitment shows a CR value of 5.705 and a probability of 0.000 . Based on these values it can be concluded that Job Satisfaction has a significant positive effect on the Commitment Organization. In other words the higher the Job Satisfaction of a female junior high school teacher in Surabaya, the more committed the teacher will be.

The results of this study are in line with Sawitri et al (2016) which show that increasing one's Job Satisfaction will increase his work commitment. This result is also in line with the research of Vukojanski et al (2014) which states that in the field of education women are more satisfied in their jobs compared to men, but in the manufacturing industry it is the opposite that men show faster satisfaction in working compared to women. This research was conducted on female teachers whose majority of their work was secondary income for their families. When Job Satisfaction is achieved, the Commitment will be sought maximally by the female teachers.

\subsection{The Effect of Work Family Conflict on Job Performance}

The estimation parameter to test the effect of Work Family Conflict on Job Performance shows a CR value of 12.845 and a probability of 0.005 . Based on these values it can be concluded that Work Family Conflict has a significant negative effect on Job performance. In other words, the higher the family conflict in the working environment of the female teacher, it will interfere with the achievement of the teacher's performance targets in her school. 
The results of this study are in line with Mukkaram et al (2012) which states that there are similarities in the characteristics of respondents with this study, namely female teachers in a Muslim-majority country. One of the main challenges faced by female teachers in Pakistan is work life conflict. Socio-cultural factors are mainly causing work life conflicts among female teachers. As a result, the performance of the teachers is low. It is proven by the findings of the research conducted with results that clearly show that work life conflicts have a negative relationship with the performance of workers. Even some studies conducted on women's work life conflicts propose that there should be a reduction in working hours for married female teachers in their workplaces to reduce the impact of work life conflicts as well as increase job involvement (Chang, 2002).

\subsection{The Effect of Commitment on Job Performance}

Estimation parameters to test the effect of Commitment on Job Performance show a CR value of 0.646 and a probability of 0.518 . Based on these values, it can be concluded that the Commitment has no effect on Job performance. In other words, the strong or weak the commitment of a female junior high school teacher in Surabaya does not affect the teacher's performance.

Research (Nasomboon, 2014) explains that leaders who are committed to the organization, work and focus towards organizational goals, will influence the value of organizational performance. Kashefi, et al (2013) states that organizational commitment greatly influences the performance of employees, indicated if organizational commitment increases, it will be followed by increased employee performance, and vice versa.

\subsection{The Effect of Job Satisfaction on Job Performance}

The estimation parameter to test the effect of Job Satisfaction on Job Performance shows a CR value of 1.118 and a probability of 0.264. Based on these values, it can be concluded that Job Satisfaction has no effect on Job performance. In other words, the high or low the level of Job Satisfaction of a female junior high school teacher in Surabaya does not have an impact on achieving the teacher's performance targets.

The results of this study are not in line with the research of Green et al (2007) which found that women showed more satisfaction with their work and provided better services in accordance with organizational requirements with better performance than men. Another study by Lyness and Heilman (2006) found that women were tighter than men in obeying work rules and showed more satisfaction so that their performance was better. This result arises because in the majority of respondents who are civil servants, they tend to have achieved status satisfaction, so satisfaction that is too high is no longer able to pressure the female teacher to work better.

\section{Conclusion}

The study found a significant influence between Emotional Intelligence on Job Satisfaction and Job Satisfaction on Commitment. These results indicate that female junior high school teachers in Surabaya have Emotional Intelligence to control themselves so that Job Satisfaction can be achieved. When Job Satisfaction is achieved, the Commitment on the basis that a teacher in Indonesia is a noble work is chosen by most women in Indonesia. Interesting when the Job Performance testing of female junior high school teachers in Surabaya was only influenced by family conflict in a negative direction, the Commitment and Job Satisfaction were not found to have an effect on Job Performance. These results indicate that Job Satisfaction and Commitment are different from the performance of a female junior high school teacher in Surabaya. When the majority of female teachers are civil servants, they must have committed to the state and satisfaction as a civil servant status no longer affects their performance. Obviously they will tend to work in a comfort zone. So that for a civil servant, it is found that the factors that influence work are conflicts of interest with the family.

A junior high school female teacher in Surabaya who tends to be disturbed by family conflicts, in this study found a negative direction, meaning that the more conflict in the family, the lower their performance. The results of this study can be used as a reference for school principals in regulating the performance of their female teachers by having to discuss the resolution of their family problems so that they do not interfere with their performance achievements. And if the principal wants to increase the work Commitment of his female teacher, the level of Job Satisfaction must be increased.

\section{References}

Arriaga, X. B., \& Agnew, C. R. (2001). Being committed: Affective, cognitive, and conative components of relationship commitment. Personality and Social Psychology Bulletin, 27, 1190-1203. https://doi.org/10.1177/0146167201279011

Aryee, S., Fields, D., \& Luk, V. (1999). A cross-cultural test of a model of the work-family interface. Journal of 
Management, 25(4), 491-511. https://doi.org/10.1177/014920639902500402

Balfour, D.L., \& Wechsler, B. (1996). Organizational commitment antecedents and outcomes in public organizations. Public Productivity and Management Review, 19(3), 256-257. https://doi.org/10.2307/3380574

Chen, C.F. (2006). Job satisfaction, organizational commitment, and flight attendants turnover intentions: A note. Journal of Air Transport Management, 2, 274-276. https://doi.org/10.1016/j.jairtraman.2006.05.001

Chang, K.M. (2002). The influence of work-family conflict and sex-role identity on married female teachers job involvement. Journal of Korean Home Economics Association, 3(1), 95-105.

Chen, I., Brown, R., Bowers, B. J., \& Chang, W. (2015). Work-to-family conflict as a mediator of the relationship between job satisfaction and turnover intention. Journal of Advanced Nursing, 71(10), 2350-2363. https://doi.org/10.1111/jan.12706

Davar, S. C., \& Bala, R. (2012). Relationship between job satisfaction \& job performance: A meta-analysis. Indian Journal of Industrial Relations, 48(2), 290-305.

Dumitrescu, L., Cetina, L., \& Pentescu, A. (2012). Employee Satisfaction Measurement - Part of Internal Marketing. Revista De Management Comparat International/Review Of International Comparative Management, 13(1), 37-48.

Ferdinand, Augusty. (2000). Structural Equation Modelling dalam Penelitian Manajemen. Semarang: BP Undip.

Semarang Foley, S., Ngoe, H. Y., \& S. Lui. (2005). The effect of work stressor, perceived organizational support, and gender on work-family conflict in Hong Kong. Asia Pacific Journal of Management, 22, $237-256$. https://doi.org/10.1007/s10490-005-3568-3

Gardner, L. (2006). Emotional intelligence and occupational stress. England: Tertiary Press.

George, J.M. (2000). Emotions and leadership: The role of emotional intelligence. Human Relations, 53(8), 1027-1055. https://doi.org/10.1177/0018726700538001

Goleman D. (1996). Emotional Intelligence-Why It Can Matter Than IQ? What Really Determines Success in Life?. Learning, 3(1), 49- 50.

Goleman, D. (2004). What makes a leader?. Harvard Business Review, 82, 82-91.

Grandey, A. A., Cordeiro, B. L., \& Crouter, A. C. (2005). A longitudinal and multi-source test of the work--family conflict and job satisfaction relationship. Journal of Occupational \& Organizational Psychology, 78(3), 305-323. https://doi.org/10.1348/096317905X26769

Green, T., Jegadeesh, N., \& Tang, Y. (2007). Gender and job performance: Evidence from Wall Street. Financial Analysts Journal, 65(6), 65-78. https://doi.org/10.3386/w12897

Halkos, G., \& Bousinakis, D. (2010). The effect of stress and satisfaction on productivity. International Journal Productivity Performance Management, 59(5), 415-431. https://doi.org/10.1108/17410401011052869

Hochwarter, W., Kiewitz, C., Gundlach, M., \& Stoner, J. (2004). The impact of vocational and social efficacy on job performance and career satisfaction. Journal of Leadership \& Organizational Studies, 10(3), 27-40. https://doi.org/10.1177/107179190401000303

Jacobs, J. A., \& Winslow, S. E. (2004). Over Worked Faculty: Job Stresses and Family Demands. The ANNALS of the American academy of Political and Social Science. 104. https://doi.org/10.1177/000271620459600105. https://doi.org/10.1177/0002716204268185

Kashefi, M.A., Adel, R.M., Abad, H.R.G., Aliklayeh, M.B.H., Moghaddam, H.K., \& Nadimi, G. (2013). Organizational Commitment and Its Effects on Organizational Performance. Interdisciplinary Journal of Contemporary Research In Business, 4(12).

Kistyanto, A, Budiono, Indawati, N., Fazlurrahman, H., Kautsar, A., \& Rahman, Z. (2018). Food Industry Performance: Entrepreneurial Leadership and Human Capital Perspective. International Journal of Mechanical Engineering and Technology, 9(6), 1199-1208.

Latif, H., Majoka, M.I., \& Khan, M.I. (2017). Emotional Intelligence and Job Performance of High School Female Teachers. Pakistan Journal of Psychological Research, 32(2), 333-351.

Linh, N.T.T, Teh C.J., Tee, P.K., \& Fah, B.J.Y. (2016). Work-Family Conflict And Employee Job Satisfaction: A Comparison Of State-Owned And Foreign-Invested Enterprises In Vietnam. Asian Economic and Social Society, 
6(4), 63-72. https://doi.org/10.18488/journal.1006/2016.6.4/1006.4.63.72

Locke, E. A. (1976). The Nature And Causes Of Job Satisfaction. Chicago: Rand McNally.

Lu, L., Cooper, C., Kao, S., Chang, T., Allen, T., Lapierre, L., O’Driscoll, M., Poelmans, S., Sanchez, J., \& Spector, P. (2010). Cross-cultural differences on work-to-family conflict and role satisfaction: A Taiwanese-British comparison. Human Resource Management, 49(1), 67-85. https://doi.org/10.1002/hrm.20334

Luthans, F. (1995). Organizational Behavior. New York : Mc Graw Hill.

Lyness, K. \& Heilman, M. (2006). When fit is fundamental: performance evaluations and promotions of upper-level female and male managers. Journal of Applied Psychology, 91(4), $777-785$. https://doi.org/10.1037/0021-9010.91.4.777

Magnini, V. P., Lee, G., \& Kim, P. B. (2011). The cascading affective consequences of exercise among hotel workers. International Journal of Contemporary Hospitality Management, 23(5), 624-643. https://doi.org/10.1108/09596111111143377

Mayer, J.D. \& Salovey P. (1993). The Intelligence of Emotional Intelligence. Intelligence, 17(4), 433-442. https://doi.org/10.1016/0160-2896(93)90010-3

Mendoza, M.L. \& Maldonado, C. O. (2014). Meta-analytic of the relationship between employee job satisfaction and customer satisfaction. Suma De Negocios, 5(11), 4-9. https://doi.org/10.1016/S2215-910X(14)70014-X

Mukarram, A, Akbar, A., Jan, Z., \& Gul, A. (2012). Work life conflict impact on Female's Job performance. A study of primary level female school teachers in Pakistan. European Journal of Business and Management, 4(20).

Nasomboon, Boonyada. (2014). The Relationship among Leadership Commitment, Organizational Performance, and Employee Engagement. International Business Research, 7(9), 77-90. https://doi.org/10.5539/ibr.v7n9p77

Netemayer, R. G., J. S. Boles, \& R. McMurrian, R. (1996). Development and validation of work-family conflict and family-work conflict scales. Journal of Applied Psychology, 81, 400-410. https://doi.org/10.1037/0021-9010.81.4.400

Perry, C. \& Ball, I. (2007). Dealing constructively with negatively evaluated emotional situations: The key to understanding the different reactions of teachers with high and low levels of emotional intelligence. Social Psychology of Education, 10, 443-454. https://doi.org/10.1007/s11218-007-9025-z

Robbins, S.P. (2008). Organizational Behaviour, Tenth Edition (Perilaku Organisasi Edisi Sepuluh). Jakarta: Salemba Empat.

Sawitri, D, Suswati, E., \& Huda, K. (2016). The Impact Of Job Satisfaction, Organization Commitment, Organization Citizenship Behavior (OCB) On Employees' Performance. The International Journal of Organizational Innovation, 9(2).

Segal, A. (1992). Corporate women. Business Week, 74-83.

Shockley, K. M., \& Singla, N. (2011). Reconsidering work-family interactions and satisfaction: A meta-analysis. Journal of Management, 37(3), 861-886. https://doi.org/10.1177/0149206310394864

Vukonjanski, J, Terek, E., \& Gligorović, B. (2014). Job Satisfaction Of Men And Women Employed In Manufacturing Sector And Education In Serbia Singidunum. Journal of Applied Science, 11(1), 25-33. https://doi.org/10.5937/sjas11-4951

Wardoyo, D.T.W., Iriani, S.S., \& Kautsar, A. (2018). Adoption of E-Commerce, Entrepreneurship Orientation Mediated by Business Strategy on The Performance Food Industries. International Journal of Civil Engineering and Technology, 9(5), 896-902.

Yavas, U., Karatepe, O. M., \& Babakus, E., (2013). Correlates of Nonwork and Work Satisfaction Among Hotel Employees: Implication for Managers. Journal of Hospitality Management, 22(4), 375-406. https://doi.org/10.1080/19368623.2012.667596 